\title{
Mexican Reduviidae, III: The genus Atrachelus (Harpactorinae) ${ }^{1}$
}

\author{
Jenaro Maldonado Capriles and Harry Brailovsky ${ }^{2}$
}

\begin{abstract}
According to the authors' data, the distribution of two subspecies of Atrachelus cinereus (Fabricius) fall in the accepted subdivision of Mexico into a Neartic, mostly northern area, and a Neotropical, mostly southern portion. $A$. c. crassicornis is recorded from the Neotropical area and A. c. wygodzinskyi from the Neartic. These findings corroborate Elkins' observation when he described the three subspecies of $A$. cinereus and studied their geographic distribution.
\end{abstract}

\section{INTRODUCTION}

Elkins ${ }^{3}$ wrote a synopsis of the genus Atrachelus. He subdivided the genus into two subgenera, namely Atrachelus Amyot and Serville, 1843 and Phorobura Stal, 1859. Stal assigned generic rank to Phorobura and separated it from Atrachelus because the males of the latter have strongly thickened third antennal segment and in both sexes the postocular margin of the head is only slightly longer than the anteocular. Elkins noticed that the thickness of the third antennal segment in the males of one geographic race of $A$. cinereus varied from lacking to slightly evident, thus it can not be used as a generic character. He also noticed that Phorobura and Atrachelus share the uncommon character of absence of gonoforceps, have similar aedeagal and basal plates in the males, and similar tergites in the females. For reasons of priority Phorobura was declared a subgenus of Atrachelus.

The subgenus Phorobura includes 9 species, none so far reported from México. Subgenus Atrachelus has only one species, A. cinereus, that ranges from Argentina to the United States. It has three morphologically well defined subspecies. Elkins key to the subspecies is copied below.

\section{Key to the subspecies of Atrachelus cinereus}

1. Spines on head and thorax rather long; dorsal thoracic spines half or more the length of basal rostral segment ...............

Spines on head and thorax short; dorsal thoracic spines less than half the length of basal rostral segment ........ cinereus wygodzinskyi Elkins

${ }^{1}$ Manuscript submitted to Editorial Board March 1, 1984.

${ }^{2}$ J. Maldonado Capriles, Ponce School of Medicine, Ponce, Puerto Rico, and Department of Plant Protection, University of Puerto Rico, Mayaguez, P. R.; and Harry Brailovsky, Instituto de Biologia, Universidad Autónoma, Ciudad de México, México 20, D. F.

${ }^{3}$ Elkins, J. C., 1954. A synopsis of Atrachelus (Hemiptera, Reduviidae). Proc. Entomol. Soc. Wash., 56(3):97-120. 
2. Legs usually concolorous, sometimes with indistinct speckled longitudinal markings or rarely with very faint annuli on femora cinereus cinereus (Fabr.)

Femora and tibiae with well defined annuli, often with additional longitudinal markings ............. cinereus crassicornis (Burm.)

Elkins observed that $A$. cinereus wygodzinskyi is associated with an average rainfall of less than $35 \mathrm{in} .(88.9 \mathrm{~mm})$ and that the typical form comes from areas in Arizona and New Mexico with an average annual precipitation of $38 \mathrm{~mm}$ or less. The distribution of this subspecies is therefore more to the west of southern United States. Elkins studied but one Mexican specimen and it seemed to be a cline between wygodzinskyi and crassicornis. The specimen came from Cuernavaca. A. c. cinereus ranges from Texas to Florida. The average precipitation in this area is over $92 \mathrm{~mm}$. A. c. crassicornis is a neotropical form whose range extends from Argentina to southern Mexico. Elkins found it impossible to associate this form with rainfall as annual precipitation varies from (18-254 $\mathrm{mm}$ ) in its range.

\section{OBSERVATIONS}

Specimens from the collection of the "Instituto de Biologia" in the "Universidad Nacional Autonoma" at Mexico City were identified by the junior author to subspecies. The morphology of the specimens agrees quite well with Elkins' descriptions and no clines were noted among them. The results of these identifications and the geographical distribution of the two forms are detailed below. All the collections represent new records for Mexico. A summary of climatological conditions is given under each subspecies group.

A. Atrachelus cinereus crassicornis; 32 males and 13 females: NAYARIT (A): Rincón de Guayabitos. JALISCO ((B): Chanela, Guadalajara. GUERRERO (C): Los Arenales. OAXACA (D): Bethania, Tuxtepec, Temazcal, and Presa Miguel Alemán. CHIAPAS (E): Huixtla, Bonampak, and Rio Lacanja (rd. Palenque Ocosingo). TABASCO (F): Teapa. VERACRUZ (G): Metlac, Puente Nacional, Tlilapán, Zongolica, San Andrés Veracruz, Los Tuxtlas, Tecolapa, Sierra de Santa Marta, Atzacán, Salto de Eyippantla, Cordillera Alemán, Plan del Río, and Orizaba. PUEBLA (H): La Esperanza. SAN LUIS POTOSI (I): Xilitla.

These states are characterized by a high annual precipitation and are considered to be in the Neotropical Realm by Halffter ${ }^{4}$.

B. Atrachelus cinereus wygodzinskyi: 24 males and 3 females: SONORA (1): Valle del Yaqui. COAHUILA (2): Matamoros. AGUAS-

${ }^{4}$ Halffter, G., 1964. La Entomofauna Americana, Ideas Acerca de su Origen y Distribución. Folia Entomol. Méx. 6:35-6. 
CALIENTES (3): Aguascalientes. HIDALGO (4): Tasquillo. ESTADO DE MEXICO (5): Texcoco. MORELOS (6): Yautepec, Cuautla, and Oaxtepec. PUEBLA (7): Puebla, Santa Lucia (Atlixco).

With the exception of Morelos, these states are characterized by a very low precipitation rate and cold weather. This part of the country is considered Neartic by Halffter.

In figure 1 the numbers identify the states where wygodzinski was collected. The numbers are placed close to collection localities and the dots represent the localities listed above. The letters correspond to states where crassicornis was collected and the dots the localities mentioned above. The states corresponding to the numbers and letters are listed below under their corresponding Realm. The black line approximately separates the Neotropical from the Neartic Realm.

\section{List I}

Collections of $A$. c. crassicornis and A. c. wygodzinskyi by Realm and State, Mexico (fig. 1).

NEARTIC

A. c. wygodzinskyi

1. Sonora

2. Coahuila

3. Aguascalientes

5. México

6. Morelos

7. Puebla
NEOTROPICAL

A. c. crassicornis

A. Nayarit

B. Jalisco

C. Guerrero

D. Oaxaca

E. Chiapas

F. Tabasco

G. Veracruz

H. Puebla

I. San Luis Potosí

\section{RESULTS}

The above records show that $A$. c. crassicornis occurs in areas with over $92 \mathrm{~mm}$ of annual rainfall, whereas $A$. c. wygodzinskyi occurs in areas with $89 \mathrm{~mm}$ or less. These data corroborate Elkins' observations. The specimens from Morelos represent the only discrepancy. Morelos has a wet and hot climate, thus more neotropical conditions.

\section{RESUMEN}

Al estudiar la distribución geográfica de dos de las tres subespecies de Atrachelus cinereus, a saber A. c. crassicornis y A. c. wygodzinskyi, se observa que respectivamente ocurren en las regiones Neotropical y Neár- 


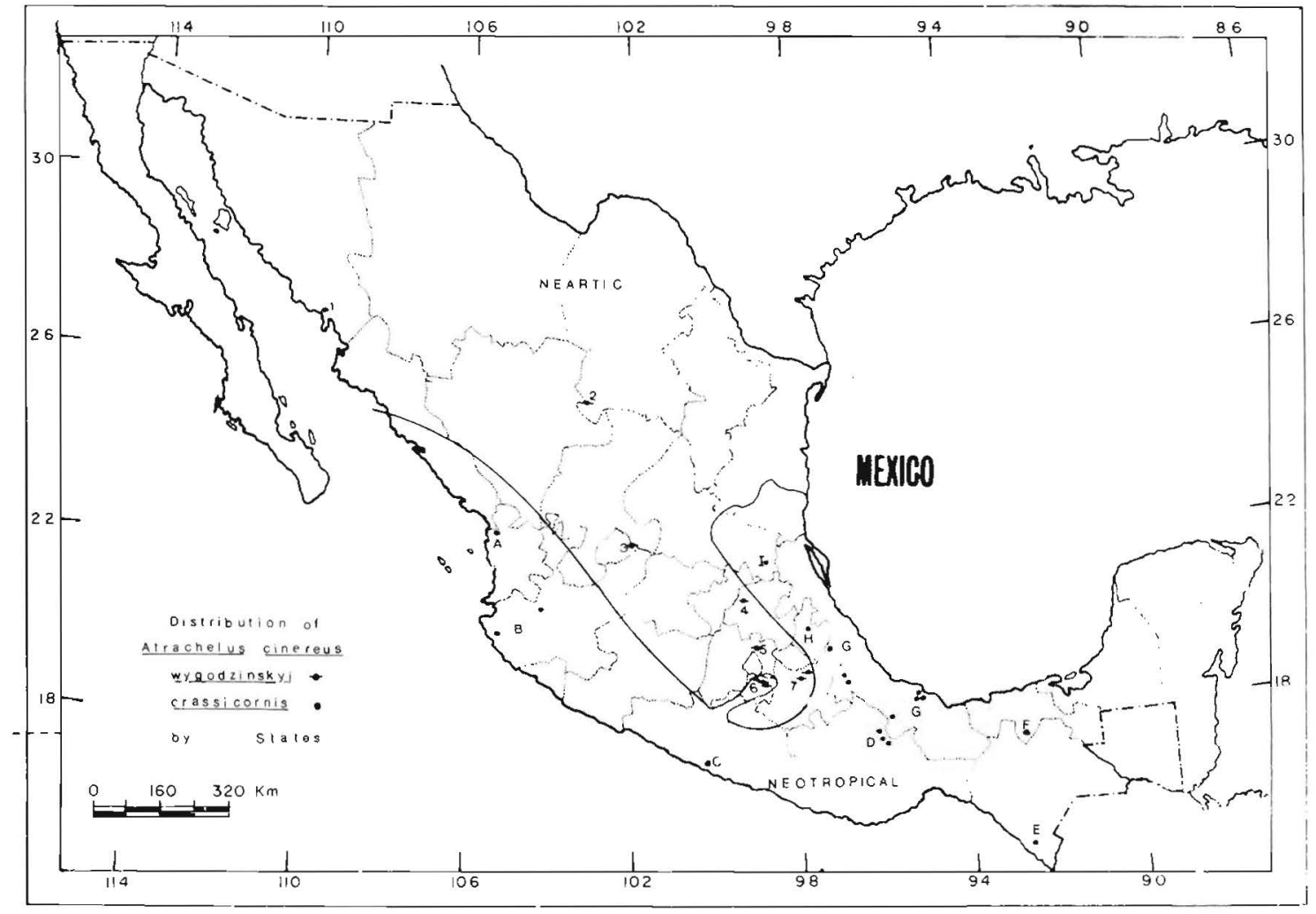

FIG. 1.-States and localities where wygodzinskyi and crassicornis were collected. 
tica en las que se subdivide México. Esto corrobora las observaciones de Elkins sobre la distribución geográfica de éstas y la tercera subespecie $A$. c. cinereus. Esta última se registró de México. Los ejemplares de Morelos presentan la única discrepancia y los autores por el momento no tratan explicarla. 